\title{
Conceptions about palliative care: literature review
}

\author{
Concepções sobre cuidados paliativos: revisão bibliográfica \\ Concepciones sobre cuidados paliativos: revisión bibliográfica
}

\section{Ednamare Pereira da Silva ${ }^{1}$, Dora Sudigursky²}

\begin{abstract}
This literature review study aimed to identify the conceptions of palliative care mentioned in Brazilian journals. The databases LILACS, SciELO and BDENF were used. In total, 47 articles were selected, published from 2000 to 2006. The conceptions found refer to the concept of palliative care, understood as integral care for individuals in terminal conditions, emphasizing the physical, psychosocial and spiritual aspects of the individual and the family; quality of life; care based on a humanistic approach and valuation of life; pain and symptom control; ethical issues about life and death; multidisciplinary approach; dying as a natural process; the priority of care over cure; communication, spirituality and mourning support. These conceptions are considered highly important in palliative care; however, there is a lack of services and centers to deliver these types of care.
\end{abstract}

Keywords: Hospice care; Terminally ill; Terminal care

\section{RESUMO}

A proposta deste estudo bibliográfico foi identificar as concepções dos cuidados paliativos, referidas em periódicos nacionais. Foram utilizadas as bases de dados LILACS, SciELO e BDENF, sendo selecionados um total de 47 artigos, publicados no período de 2000 a 2006. As concepções encontradas referem-se ao conceito de cuidados paliativos, entendido como cuidado integral voltado para indivíduos em condições terminais, com ênfase no aspecto físico, psicossocial e espiritual do indivíduo e família; qualidade de vida; cuidado baseado em uma abordagem humanística e de valorização da vida; o controle da dor e dos demais sintomas; as questões éticas sobre a vida e a morte; a abordagem multidisciplinar; o morrer como processo natural; a prioridade do cuidado sobre a cura; a comunicação, a espiritualidade e o apoio ao luto. Considera-se que estas concepções assumem grande importância nos cuidados paliativos, no entanto, existe uma lacuna de serviços e núcleos para realizar estes cuidados.

Descritores: Cuidados paliativos; Doente terminal; Assistência terminal

\section{RESUMEN}

La propuesta de este estudio bibliográfico fue identificar las concepciones de los cuidados paliativos, referidas en periódicos nacionales. Para ello se utilizaron las bases de datos LILACS, SciELO y BDENF, siendo seleccionados un total de 47 artículos, publicados en el período del 2000 al 2006. Las concepciones encontradas se refieren al concepto de cuidados paliativos, entendido como un cuidado integral volcado a individuos en condiciones terminales, con énfasis en el aspecto físico, psicosocial y espiritual del individuo y familia; calidad de vida; cuidado basado en un abordaje humanístico y de valorización de la vida; el control del dolor y de los demás síntomas; las cuestiones éticas sobre la vida y la muerte; el abordaje multidisciplinario; el morir como proceso natural; la prioridad del cuidado sobre la curación; la comunicación, la espiritualidad y el apoyo en el luto. Se considera que estas concepciones asumen gran importancia en los cuidados paliativos, entre tanto, existe una laguna de servicios y núcleos para realizar estos cuidados.

Descriptores: Cuidados paliativos; Enfermo terminal; Cuidado terminal

\footnotetext{
${ }^{1}$ RN, graduate at Escola de Enfermagem at Universidade Federal da Babia - EEUFBA - Salvador (BA), Brazil.

${ }^{2}$ RN, Ph.D, professor at Escola de Enfermagem at Universidade Federal da Babia - EEUFBA - Salvador (BA), Brazil.
} 


\section{INTRODUCTION}

The patient without therapeutic possibilities of cure, not only terminally, but during the whole course of the disease, presents fragilities and very specific limitations of physical, psychological, social and spiritual nature. These patients, for whom science does not have resources to deter the deadly advancement of the disease, arouse questions to the healthcare team, family members and the individuals themselves ${ }^{(1)}$. This gives rise to the need for a specific care method.

This care, also named end-of-life care, primordially emerged to help patients with cancer in an advanced stage, extending to every patient afflicted by a disease that causes intense pain, besides physical symptoms, emotional and spiritual suffering so intense that they make life extremely unbearable ${ }^{(2)}$. This care is directed at patients beyond the possibility of cure, since the disease is already progressive, irreversible and non-responsive to the curative treatment. The objective of this care is to provide quality of life in the final moments.

As such, palliative care is defined as a way of helping people whose disease is not responsive to the curative treatment, and is characterized by the control of physical and psychological signs and symptoms that are proper of the incurable disease's advanced stage ${ }^{(3)}$.

In 1990, the World Health Organization (WHO) conceived palliative care as active and total care for patients whose disease does not respond to the curative treatment anymore, prioritizing pain control, as well as the control of symptoms and psychological, social and spiritual problems, aiming at providing the best quality of life to patients and their families ${ }^{(4)}$.

The concept of palliative care had its origin in the hospice movement, idealized by Dame Cecily Saunders, who described the philosophy of care for the person who is dying, with a view to relieving physical, psychological, social and spiritual suffering ${ }^{(2)}$, exclusively aiming at caring.

This theme was chosen due to its relevance since, even with all the technology available and applied to deliver care or prolong life; a wide range of patients do not benefit from this advanced medicine. Therefore, these patients do not have the benefit of the cure, and their only alternative is to receive care based on the philosophy of palliative care, which becomes important in the healthcare area as a specific type of care for patients beyond the therapeutic possibilities of cure.

\section{METHODS}

This is a literature review, using the online databases LILACS, SciELO and BDENF.

Initially, the search looked at the production of knowledge on palliative care mentioned in Brazilian journals, through a literature review about the theme.

The initial search included the article titles and abstracts of a wide selection of works that would be of interest, by retrieving the abstracts (from those articles without accessible text) and the full texts of the articles, using the terms palliative care, terminal patient, terminal care and palliative assistance as key words.

The criteria for inclusion considered texts on the principles of palliative care, Brazilian texts (aiming at bringing the discussion closer to the national context) and texts published between 2000 and 2006 (researching preferably recent publications). Sixty-four articles referring to palliative care were found, and texts that did not meet the established criteria were excluded.

In the end, 47 articles were selected, organized in cards with data about the identification of the articles and a synthesis to apprehend the conceptions about palliative care.

\section{RESULTS}

Of the 47 articles selected, 7 were published in 2006 , 8 in 2005, 7 in 2004, 14 in 2003, 5 in 2002, 4 in 2001 and 2 in 2000, pointing to a crescent interest in the palliative care theme, since there was a predominance of publications in the four last years, especially in 2003. The importance of the LILACS database is noteworthy, where all the selected journals were indexed, particularly the journal Mundo Saúde, from which 14 articles were selected.

Regarding the type of journal the articles were published in, journals that addressed current healthcare fields from a multidisciplinary perspective stood out, however, without the predominance of any periodical in a specific area.

Thus, the conceptions about palliative care found in the 47 articles were: quality of life, humanistic approach and valuation of life, control and relief of pain and assorted symptoms, ethical issues, multidisciplinary approach, dying as a natural process, the priority of care over cure, communication, spirituality and support in mourning. In the articles, these conceptions showed to be intimately interlinked or even interdependent.

\section{DISCUSSION}

The process of care/caring is inherent to the human person. Therefore, we need to care for and be cared for during our life cycle. At the end of this cycle, the need for a peculiar type of care arises, impregnated by the valuation of being. This is the essence of palliative care.

Nowadays, palliative care has been extended to the neonatal and pediatric areas, in response to the pediatric 
specialties of hematology, oncology, to extremely preterm babies, babies with serious congenial malformation, among other rare diseases ${ }^{(5-6)}$. Here, the concept of palliative care also obeys to the definition of effective and integral healthcare, directed at children and teenagers outside therapeutic possibilities of cure, and their relatives. However, little has been written about palliative care in pediatrics ${ }^{(6)}$, but we know that grave and chronic diseases that lead to death also afflict children and adolescents. Palliative care should also look at the process of death and dying in these cases.

Also, by reflecting on the concept of palliative care, the texts appoint that the need for palliative care does not only occur at the moment of finitude, but in all stages of life, and also during the evolution of chronicdegenerative diseases ${ }^{(7)}$. Therefore, many of the palliative care principles are also applied in early stages of the disease, combined with specific therapies for the pathological process ${ }^{(8)}$, understanding that the disease certainly causes changes in different aspects of the sick individual. Therefore, the conceptions found about palliative care were:

Quality of life: When cure is no longer possible, the focus of care delivery to the patient is the search for quality of life at the moment of finitude, which should be met through comfort, symptoms relief and control , spiritual and psychosocial support and, also, support in the process of mourning, i.e. providing quality of life to the patient and the family during the final moments. The conception of quality of life as something extremely important for the patient and the family is present in all texts analyzed, with palliative care being recognized as an approach that improves this quality of life.

Humanistic approach and valuation of life: Conceptions with a strictly humanistic character, such as compassion, humbleness, honesty and valuation of life emerged from the texts ${ }^{(1,8-13)}$. They support the philosophy of palliative care as a type of care that is close to the ideal of sensitive and efficient care/caring, here understood as the adoption of measures and actions that respect and comprehend the individual as a social being, with individual values, beliefs and necessities. The valuation of life entails the concept of meaningfulness, i.e. the sense and conviction of a purposeful life, where each performs a role, with life being understood as a gift of God and, finally, conceiving the meaning of life as living it in its whole dimension ${ }^{(10)}$.

Control and relief of pain and other symptoms: The conception of adequate control and relief of pain and other symptoms as the main focus of palliative care emerged in all texts accessed. Pain occurs in individuals experiencing a series of physical, psychic, social and spiritual discomforts, such as skin injuries, nauseating odors, anorexia, cachexia, insomnia, fatigue, anticipated mourning, economic difficulties and depression, among others $^{(14)}$. In practice, it is known that mismanaged pain causes impacts beyond the physical scope, affecting the sick individual as well as the family and healthcare professionals. The term "total pain" originated there, since pain in human beings is a situation that, besides nociception (amount of injured tissue), involves physical, emotional, social and spiritual factors, which influence the experience of complaining about pain ${ }^{(14)}$.

Hence, control and relief of pain and other symptoms is an individual right for the patient and a duty for the professionals, who should create strategies to decrease the suffering caused by this situation.

Ethical issues: There were countless ethical reflections about palliative care in the analyzed texts, such as the five ethical principles that guide palliative medicine. These are called the principles of truthfulness (always telling the truth to patients and their families), therapeutic proportionality (only adopting useful therapeutic measures), double effect (the positive effects must outweigh the negative ones), prevention (predicting complications, counseling the family) and nonabandonment (always showing solidarity, supporting the patient and the family at all times) $)^{(15)}$.

Issues like dignity in the process of dying, autonomy to decide about one's own life, non-abbreviation of life or artificial prolonging, promoting beneficence, non-maleficence and justice, also emerged from the texts $^{(8,13,15-18)}$.

By analyzing these issues, it can be deduced that palliative care aims to promote humanization in the final moments of life, through an approach that can provide dignity at the time of death, guided by ethical principles of respect for human life.

Multidisciplinary approach: The conception of a multidisciplinary approach to the individual and the family denotes an indispensable aspect in the philosophy of palliative care, because this type of care is directed at physical, psychological, spiritual and social symptoms, needing different types of professionals for care delivery.

Thus, the multidisciplinary approach becomes important, since the problems of the patient and the family involve multiple aspects. It is worth observing these problems from different perspectives so that care can be performed uniformly, by establishing common goals, aiming to promote integral care and dignity in the process of dying.

Dying as a natural process: We know that death is our incontestable truth and, in spite of the advances of science that try to prolong life as much as possible, death is certain.

Death, faced as a natural process, where all meanings should be discussed with the patient, family and healthcare professional, makes the process of dying less 
painful, involved in an atmosphere of peace and serenity. Therefore, we should be aware that we are beings submitted to an irreversible process that includes being born, growing up, growing old and dying ${ }^{(19)}$.

The priority of care over cure: in palliative care, understood as care directed at patients beyond therapeutic possibilities, where cure is no longer feasible, caring becomes indispensable.

Hence, the main focus of palliative medicine is caring, which has priority over a cure, since there is no sure way to tell whether our diseases can be cured or that our death can be avoided ${ }^{(10,15)}$.

By analyzing this conception, it can be said that care should be independent from cure. Professionals often prioritize the cure and, when this is not attained, they feel impotent and forget about caring. The latter is extremely relevant, since we cannot live without being cared for.

Care is the cornerstone of respect and valuation of human dignity, which everything else should be built upon $^{(15)}$.

Communication: The articles describe the importance of frank and honest communication (both verbal and non-verbal) among patient, family and professional team ${ }^{(9,20-21)}$.

Hence, communication is fundamental in the therapeutic relation that is established between the team and the patient/family, aiming to establish a relation of effective aid, within an adequate environment, where patient and family can reveal their fears, sorrows, values and meanings. Professionals need to be truthful and sincere, providing concrete and real information, so that this relation can be marked by total trust.

Spirituality and support in mourning: It is known that both the individuals who are dying and their family

\section{REFERENCES}

1. Menezes RA. Em busca da boa morte: antropologia dos cuidados paliativos. Rio de Janeiro: Editora Fiocruz: Garamond; c2004.

2. McCoughlan M. A necessidade de cuidados paliativos. Mundo Saúde (1995). 2003; 27(1): 6-14.

3. Firmino F. Pacientes portadores de feridas neoplásicas em serviços de cuidados paliativos: contribuições para a elaboração de protocolos de intervenção de enfermagem. Rev Bras Cancerol. 2005; 51(4); 347-59.

4. World Health Organization. WHO Expert Committee on Cancer Pain Relief and Active Supportive Care. Cancer pain relief and palliative care: Report of a WHO Expert Committee. Geneva: World Health Organization; 1990. 75 p. (Technical Report Series (WHO), 804).

5. Carvalho MVB, Perina EM. Cuidados paliativos pediátricos: a essência do cuidar da criança/adolescente/familiares nas situações limites. Mundo Saúde (1995). 2003; 27(1): 93-7.

6. Costa SMM, Duarte CAM, Salcedo EAC, Perina EM, Souza JL, Bianchi MO, et al. Cuidados paliativos em neonatologia: implementação de um programa multiprofissional. Mundo face existential issues (perception of meaning, peace, hope and purpose of life) ${ }^{(21)}$, in which their beliefs and values exert a strong influence on how to experience the process of death and dying. This gives rise to the need to relieve spiritual suffering, not only during the course of the disease, but also during mourning, with the support of the multidisciplinary team in all aspects.

Mourning is marked as a moment, an experience of responding to the breaking of the bond ${ }^{(22)}$. It is the awareness of losses, of the breaking of an affectionate relation, becoming an extremely painful moment. This is why mourning becomes important in the philosophy of palliative care and constitutes an object of action.

\section{FINAL CONSIDERATIONS}

Based on the selected articles, the importance of palliative care could be verified in healthcare for patients beyond therapeutic possibilities of cure, where the process of caring is a priority over the process of treating.

In palliative care, the relevance given to the humanistic approach was observed, based on the valuation of life and comprehension of death as a natural condition, centered on the individual and the family, having a multidisciplinary character in the sense of controlling and relieving not only the physical suffering, but also the psychosocial and spiritual grievances of the individual, so that integral care could be reached, guided by the ethical principles of human rights.

Finally, based on data revealed in the studied articles, the need to educate professionals and create palliative care services was observed, because Brazil has neither physical nor human infrastructure to meet the demand for this type of care, with a real gap in care delivery to patients beyond the therapeutic possibilities of cure.

Saúde (1995). 2003; 27(1): 171-6.

7. Rego S, Palácios M. A finitude humana e a saúde pública. Cad Saude Publica = Rep Public Health. 2006; 22(8): 175560.

8. Silva CHD. A moralidade dos cuidados paliativos. Rev Bras Cancerol. 2004; 50(4): 330-3.

9. Marcucci FCI. O papel da fisioterapia nos cuidados paliativos a pacientes com câncer. Rev Bras Cancerol. 2005; 51(1): $67-$ 77.

10. Melo AGC. Os cuidados paliativos no Brasil. Mundo Saúde (1995). 2003; 27(1): 58-63.

11. Kovács MJ. Comunicação nos programas de cuidados paliativos: uma abordagem multidisciplinar. Mundo Saúde (1995). 2003; 27(1): 71-80.

12. Lepargneur H. Um poeta fala nos últimos dias do ser humano: introdução aos cuidados paliativos. Mundo Saúde (1995). 2003; 27(1): 185-9.

13. Gomes APR, Almeida HO. A morte no contexto dos serviços de saúde. Rev Saude Dist Fed. 2004; 15(1/2): 1932. 
14. Pimenta CAM. Dor oncológica: bases para a avaliação e tratamento. Mundo Saúde (1995). 2003; 27(1): 98-110.

15. Pessini L. A filosofia dos cuidados paliativos: uma resposta diante da obstinação terapêutica. Mundo Saúde (1995). 2003; 27(1): 15-32.

16. Souza LB, Souza LEEM, Souza AMA. A ética no cuidado durante o processo de morrer: relato de experiência. Rev Bras Enferm. 2005; 58(6): 731-4.

17. Kovács MJ. Bioética nas questões da vida e da morte. Psicol USP. 2003; 14(2): 115-67.

18. Trindade EMV. Uma perspectiva histórica do sofrimento humano: considerações éticas no âmbito da saúde. Rev
Saúde Dist Fed. 2004; 15(1/2): 9-18.

19. Schramm FR. Morte e finitude em nossa sociedade: implicações no ensino dos cuidados paliativos. Rev Bras Cancerol. 2002; 48(1): 17-20.

20. Rodrigues IG, Zago MMF, Caliri MH. Uma análise do conceito de cuidados paliativos no Brasil. Mundo Saúde (1995). 2005; 29(2): 147-54.

21. Silva MJP. Comunicação com paciente fora de possibilidades terapêuticas: reflexões. Mundo Saúde (1995). 2003; 27(1): 64-70.

22. Breitbart W. Spirituality and meaning in palliative care. Mundo Saúde (1995). 2003; 27(1):33-44. 